\title{
Critical periods of sorghum and palisadegrass in intercropped cultivation for climatic risk zoning
}

\author{
Nino Rodrigo Cabral de Barros Lima ${ }^{1^{*}}$, Patricia Menezes Santos ${ }^{2}$, Fernando Campos \\ Mendonça ${ }^{2}$, Leandro Coelho de Araujo ${ }^{1}$ \\ ${ }^{1}$ ESALQ/USP - Av. Pádua Dias, 11, 13418-900, Piracicaba, SP, Brasil. \\ ${ }^{2}$ Embrapa Pecuária Sudeste, São Carlos, SP, Brasil.
}

ABSTRACT - The objective of this work was to define critical periods for sorghum and palisadegrass cultivated on crop-livestock integrated systems under water deficit. An experiment was carried out in a completely random block design with four treatments (control and interruption of water supply in three periods) and three replicates. Water supply was interrupted until soil water humidity was close to permanent wilting point at the phases: germination of palisadegrass seeds; start of tillering of palisadegrass and initiation of panicles of shorghum; start of shorghum flowering. Water deficit starting at palisadegrass germination delayed intital development of the plants because of the reduction in tillering. Water restriction at panicle initiation phase and at sorghum flowering determined reduction of grain production. Critical periods for intercrop of sorghum and palisadegrass correspond to palisadegrass germination phase and flowering and panicle inititation phase of sorghum.

Key Words: abiotic stress, Brachiaria brizantha, crop-livestock integrated systems, drought

\section{Introduction}

Weather risk zoning allows the location of agricultural areas with lower probability of occurrence of events which restrict production development. In Brazil, drought is the main determinant factor regarding the losses in the agriculture (Brasil, 2009) inasmuch as the lack of water in the soil interferes in the water relationships, in the plants physiology and morphology, about to cause water stress (Taiz \& Zeiger, 2004).

Water stress occurs when the rate of transpiration exceeds the absorption and the water transportation in the plant (Berkowitg, 1998). The low availability of water in the soil causes dehydration of the plants, growth reduction and the senescence acceleration of their tissues, impairing growth due to the rate reduction of the leaf expansion, photosynthesis reduction (Bennett \& Sullivan, 1981) and rate reduction of leaves emergence (Van Loo, 1992). The magnitude at which the water deficit affects the leaf area reduction and, consequently, the growth and the production depends on the relationship between the expansion rate and the leaf water potential during stress and recovery after rain or irrigation (Ludlow \& NG, 1976).

When associating the studies on climate data to the water deficit effects in the production, it is possible to determine the most suitable periods for planting, to reduce the probability of water stress at crucial moments for the production development.

Agricultural zoning with weather risk is made by analyzing soil variables, climate and plant and by applying mathematical and statistical function (frequency and probability) with the objective to quantify the farming loss risk due to the occurrence of adverse climate events, mainly drought (Brasil, 2009).

Therefore, it is determined for each city/town, the best season for crops in different types of soil and cycles of cultivars (Brasil, 2009).

The objective of this work was to define critical periods for Sorghum bicolor and palisadegrass production cultivated in intercrop and submitted to water deficit.

\section{Material and Methods}

This experiment was carried out in the experimental field at Embrapa Pecuária Sudeste in São Carlos, São Paulo

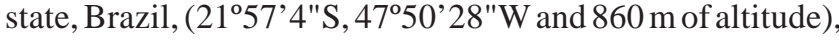
from March to September, 2008. The local climate is denominated as a humid subtropical climate with a hot weather and dry winter (Koeppen's classification: Cwa). The annual average maximal temperature and minimal temperature are $27.1^{\circ} \mathrm{C}$ and $15.9^{\circ} \mathrm{C}$, respectively. Air average

Received February 25, 2010 and accepted December 29, 2010.

Corresponding author:ninorodrigo@gmail.com

* Current address: Agência de Desenvolvimento Agrário e Extensão Rural - Rua $1^{\circ}$ de Março, 363, Centro, 79220-000, Nioaque, MS, Brasil. 
temperature is $21.5^{\circ} \mathrm{C}$ and local accumulated precipitation is $1,356 \mathrm{~mm}$ respectively (1991 to 2006).

The monthly average values for air average temperature, air relative humidity and the accumulated precipitation and evaporation were also recorded (Table 1).

The local soil is classified as Oxisol (US, 1999). Before setting up the experiment, some soil samples were collected for chemical analysis ( 0 to $20 \mathrm{~cm}$ and 20 to $40 \mathrm{~cm}$; Tables 2 and 3) and physical-hydric (from 10 to $10 \mathrm{~cm}$ to $100 \mathrm{~cm}$ depth; Table 4).

The evaluated cultivation system was sorghum (Sorghum bicolor cultivar AG1018) intercropped with palisadegrass (Brachiaria brizantha cv. Marandu), using a complete random block design with four treatments and three replicates. The experimental plots had an area corresponding to $144 \mathrm{~m}^{2}(12 \times 12 \mathrm{~m})$.

The treatments concerned to the irrigation interruption in different periods of the production development were the following: control = without water deficit; pasture_G = shortage from the $B$. brizantha germination; pasture_T = shortage at the beginning of the $B$. brizantha tillering and at the initiation of sorghum panicles (growth stage II) and sorghum_F = shortage at the beginning of sorghum flowering (growth stage III).

In water deficit treatments, the irrigation shortage was kept until the moisture in the 0 to $60 \mathrm{~cm}$ soil layer reached average values close to $10.6 \%$ based on dry weight, which corresponds to the average moisture values in the considered soil profile, close to the permanent wilt point (Table 4). The soil moisture in the plots submitted to water deficit was determined by the gravimetric method.
Sorghum and pasture were sowed mechanically on March $6^{\text {th }}, 2008$, sowing the palisadegrass first by using a seeder proper for pasture in $0.20 \mathrm{~m}$ distant rows and $8 \mathrm{~cm}$ depth by using $20 \mathrm{~kg} / \mathrm{ha}$ of seeds with cultivation value of $40 \%$. Afterwards, the sorghum was sowed by using proper seeder, in $0.80 \mathrm{~m}$ distant rows and $4 \mathrm{~cm}$ depth, using sowing density corresponding to 16 seeds/linear m.

The amount of fertilizer applied at the bottom of the experimental area (concomitant to the sorghum sowing) following technical recommendations for sorghum production (van Raij et al., 1996), was distributed only in the sorghum rows. The fertilizer used was the formulated 08-28-16 (N-P-K) at the quantity of $312 \mathrm{~kg} / \mathrm{ha}$. Covering fertilization was carried out on April $10^{\text {th }}, 2008$ when sorghum presented approximately seven leaves by applying $246 \mathrm{~kg} /$ ha of the 25-00-25 formula. After sorghum harvest, nitrogen fertilization (August 20 th $/ 2008$ ) with $143 \mathrm{~kg} / \mathrm{ha}$ of urea was done.

Water conditions favorable to the development of the intercrop were kept through an irrigation system by conventional spraying with sectorial sprays, allowing to stop the irrigation only in the plot which was under water deficit. Irrigation management was performed according to the programmed treatments, in which the water to be applied was determined by using the "EPS" method (Rassini, 2002).

During the experiment, the plots under water deficit were covered with portable greenhouses, like a tunnel for example, to avoid soil moisture increase because of the rain (Araujo, 2008).

Table 1 - Average climate data during the experimental period (2008)

\begin{tabular}{lcccc}
\hline Month & \multicolumn{2}{c}{ Monthly averages } & \multicolumn{2}{c}{ Monthly total } \\
\cline { 2 - 5 } & $\begin{array}{c}\text { Air temperature } \\
\left({ }^{\circ} \mathrm{C}\right)\end{array}$ & $\begin{array}{c}\text { Air relative humidity } \\
(\%)\end{array}$ & $\begin{array}{c}\text { Accumulated precipitation } \\
(\mathrm{mm})\end{array}$ & $\begin{array}{c}\text { Accumulated evaporation }{ }^{1} \\
(\mathrm{~mm})\end{array}$ \\
\hline March & 23 & 76 & 156 & 101 \\
April & 22 & 69 & 142 & 78 \\
May & 18 & 73 & 39 & 99 \\
June & 18 & 74 & 22 & 82 \\
July & 18 & 56 & 34 & 161 \\
August & 20 & 64 & 30 & 163 \\
September & 20 & 60 & & 176 \\
\hline
\end{tabular}

${ }^{1}$ Piche evaporimeter.

Table 2 - Chemical Analysis (macronutrients) of the experimental area soil

\begin{tabular}{|c|c|c|c|c|c|c|c|c|c|c|c|}
\hline \multirow[t]{2}{*}{ Depth $(\mathrm{cm})$} & \multirow[t]{2}{*}{$\begin{array}{c}\mathrm{pH} \\
\left(\mathrm{H}_{2} \mathrm{O}\right)\end{array}$} & \multirow[t]{2}{*}{$\begin{array}{c}\mathrm{pH} \\
\left(\mathrm{CaCl}_{2}\right)\end{array}$} & \multirow[t]{2}{*}{$\begin{array}{c}\text { Organic } \\
\text { matter } \\
\left(\mathrm{g} / \mathrm{dm}^{3}\right)\end{array}$} & \multirow[t]{2}{*}{$\begin{array}{l}\text { P-resin } \\
\left(\mathrm{mg} / \mathrm{dm}^{3}\right)\end{array}$} & $\mathrm{K}$ & $\mathrm{Ca}^{2+}$ & $\mathrm{Mg}^{2+}$ & $\mathrm{H}+\mathrm{Al}^{3+}$ & $\begin{array}{c}\text { Cation } \\
\text { exchange } \\
\text { capacity }\end{array}$ & $\begin{array}{c}\text { Sum of } \\
\text { bases }\end{array}$ & \multirow[t]{2}{*}{$\begin{array}{c}\text { Base } \\
\text { saturation } \\
(\%)\end{array}$} \\
\hline & & & & & & & \multicolumn{4}{|c|}{ 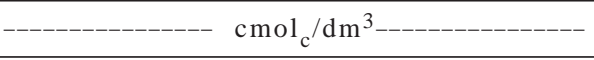 } & \\
\hline $0-20$ & 6.6 & 5.5 & 27 & 8 & 0.25 & 2.3 & 1.3 & 0.8 & 5.7 & 3.8 & 68 \\
\hline $20-40$ & 6.3 & 5.3 & 18 & 5 & 0.16 & 1.4 & 0.7 & 2.0 & 4.2 & 2.3 & 54 \\
\hline
\end{tabular}


To avoid high temperatures inside the greenhouses, plastic film was raised in the laterals, allowing air circulation and it was lowered down only when the weather was windy or with heavy rains.

The analyzed variables for palisadegrass and sorghum production were: productivity of the herbage mass (fraction above the ground) and its fractions (green leaf, green stems + sheaths and senescent material), leaf area index (LAI) and specific leaf area (SLA). For the sorghum production, the large number of plants density and the grains productivity were evaluated and, for the palisadegrass, the large number of tillering density was evaluated.

The large number of palisadegrass tillers density was evaluated every week from the beginning of the tillering by using two rectangles $(0.8 \times 1.0 \mathrm{~m})$ per plot. The other variables were evaluated during the sorghum flowering (May $17^{\text {th }}, 2008$ ) and at the moment of the harvest of sorghum grains, when the grains presented around $13 \%$ of moisture (August $6^{\text {th }}, 2008$ ).

Biomass productivity of the herbage mass of the palisadegrass was evaluated by getting the existing matter in two $0.8 \times 10 \mathrm{~m}$ rectangles. Samples were oven-dried $\left(65^{\circ} \mathrm{C}, 72\right.$ hours) for dry matter analyses.

Sorghum plants were counted in two central rows of $1.0 \mathrm{~m}$ each per plot, and afterwards the plants were harvested from ground level to estimate the the herbage mass production. The determination of the dry matter level of the sorghum plant was done according to what was described earlier for the palisadegrass.

Leaf area index (LAI) was determined through the relationship between the total leaf area and the soil total area. The leaf area was determined by the integrator model LI-3100C (Li-Cor, Lincoln, Nebraska, USA), when the evaluations were done at the same dates of herbage mass determination. The SLA was determined through the rate between the leaf area and the leaf dry matter $\left(\mathrm{cm}^{2} / \mathrm{g}\right)$.

Grain production of two samples per sorghum plot was weighed; each sample was collected in a linear meter (kg/ha).

Data statistical analysis was done by using SISVAR v.4.6 and SAS v.9.1 statistics application, according to a complete block design.

Table 3 - Chemical Analysis (micronutrients) of the experimental area soil

\begin{tabular}{lcccccc}
\hline Depth $(\mathrm{cm})$ & $\mathrm{S} \mathrm{SO}_{4}$ & $\mathrm{~B}$ & $\mathrm{Cu}$ & $\mathrm{Fe}$ & $\mathrm{Mn}$ & $\mathrm{Zn}$ \\
\cline { 2 - 7 } & --------------- & $\mathrm{mg} / \mathrm{dm}^{3}$ & --------------- \\
\hline $0-20$ & 7 & 0.23 & 0.6 & 33 & 8.3 & 1.2 \\
$20-40$ & 11 & 0.13 & 0.5 & 18 & 4.8 & 0.5 \\
\hline $\mathrm{S}^{-\mathrm{SO}_{4}=}$ organic sulfur.
\end{tabular}

For the variable density large amount of palisadegrass tillers, variance analysis was done by using a mixed pattern (PROC MIXED; SAS) in which the treatments and the evaluations were considered as fixed effects and the blocks as random effects.

The production data of the sorghum herbage mass on the second harvest were converted before the analysis $(\mathrm{Y}+1$ square root), according to suggestions by Banzatto \& Kronka (2005) because they presented irregular heterocedasticity (treatments variance are not homegenous) due to the null production in some treatments. Afterwards, the variance analysis through the minimum square method was done (SISVAR 4.6; Ferreira, 2008). For the other variables, the variance analysis was done through minimum square method by using the PROC GLM of the SAS. The treatment averages were compared by Tukey test considering the probability at $5 \%$ of significance.

\section{Results and Discussion}

The larger amount of sorghum did not differ in the studied treatments and presented an average density corresponding to $148,437(\mathrm{P}=0.1484)$ and $140,625(\mathrm{P}=0.5593)$ plants/ha for the first and second harvest, respectively.

For sorghum production; in the first harvest, there was not treatment effect on the dry matter of leaves $(\mathrm{P}=0.1266$; $1492 \mathrm{~kg} / \mathrm{ha})$ and stems $(\mathrm{P}=0.7391 ; 2203 \mathrm{~kg} / \mathrm{ha})$, LAI $(\mathrm{P}=0.3481 ; 2.5)$ and the SLA $\left(\mathrm{P}=0.3925 ; 17 \mathrm{~cm}^{2} / \mathrm{g}\right)$. However, the panicle dry matter was lower in the Pasture_T treatment $(\mathrm{P}<0.0004$; Table 5).

The second sampling of the herbage mass did not present difference for the stem dry matter yield $(2115 \mathrm{~kg} / \mathrm{ha}$; $\mathrm{P}=0.4402$ ), senescent material (937 kg/ha; $\mathrm{P}=0.2087$ ) and leaf area index $(0.20 ; \mathrm{P}=0.0964)$. However, it differed for the leaf dry matter yield $(\mathrm{P}=0.0037)$ and specific leaf area (Table 6).

The high production of leaf dry matter and specific leaf area in the Sorghum_F and in the Pasture_T (Table 6) are because these treatments were submitted to water deficit in the reproduction period, when in normal conditions, the reproductive organs would be the most predominant drain of the plant. Therefore, the water deficit in these treatments delayed leaf senescence (Table 6) and reduced the grain development (Table 6), reducing the plant reproduction drain.

According to Moraes et al. (1995), there is a hierarchy regarding the assimilate partitioning for different compartment development which compose the vegetal biomass. When there is lack of limitations of temperature, water nitrogen and light resource, the priority of the 
Table 4 - Moisture and soil bulk density at 10-60 cm of depth

\begin{tabular}{|c|c|c|c|c|c|c|c|c|}
\hline \multirow{4}{*}{ Depth (cm) } & \multicolumn{6}{|c|}{ Soil water retention curve } & & \multirow{3}{*}{ Bulk density } \\
\hline & \multicolumn{6}{|c|}{ Matric potential (MPa) } & \multirow[b]{2}{*}{-1.500} & \\
\hline & 0.000 & -0.010 & -0.033 & -0.060 & -0.100 & -0.800 & & \\
\hline & \multicolumn{6}{|c|}{ Moisture (g/100g) } & & $\mathrm{g} / \mathrm{cm}^{3}$ \\
\hline 10 & 43.18 & 20.42 & 17.81 & 15.71 & 14.50 & 13.43 & 12.01 & 1.30 \\
\hline 20 & 36.84 & 16.67 & 14.43 & 13.07 & 12.02 & 10.61 & 9.82 & 1.36 \\
\hline 50 & 36.34 & 16.53 & 14.66 & 12.80 & 11.99 & 10.90 & 10.63 & 1.53 \\
\hline 60 & 27.54 & 16.31 & 15.68 & 13.21 & 12.44 & 11.28 & 10.96 & 1.56 \\
\hline
\end{tabular}

Table 5 - Dry matter of the sorghum panicle in the first collect

\begin{tabular}{lc}
\hline Treatment $^{1}$ & Dry matter $(\mathrm{kg} / \mathrm{ha})$ \\
\hline Control & $906 \mathrm{a}$ \\
Pasture_G & $802 \mathrm{a}$ \\
Pasture_T & $340 \mathrm{~b}$ \\
Sorghum_F & $796 \mathrm{a}$ \\
CV $(\%)$ & 24.26 \\
\hline
\end{tabular}

${ }^{1}$ Control= no water deficit. Pasture_G $=$ water supply shortage from the B. brizantha germination, Pasture_T = water supply shortage at the beginning of the $B$. brizantha tillering and at the initiation of the Sorghum bicolor panicle (growth stage II) and Sorghum_F = water supply shortage at the beginning of the Sorghum flowering (growth stage III).

Average followed by the same letter in the column do not differ by Tukey test at $5 \%$ of significant level. CV $=$ coefficient of variation.

Table 6 - Converted data average $(Y+1.0$ square root) of leaf dry matter and specific leaf area of sorghum in the second collection

\begin{tabular}{lcc}
\hline Treatment $^{1}$ & Leaf $(\mathrm{kg} / \mathrm{ha})$ & Specific leaf area $\left(\mathrm{cm}^{2} / \mathrm{g}\right)$ \\
\hline Control & $1(0) \mathrm{c}$ & $1(0) \mathrm{c}$ \\
Pasture_G & $2(16) \mathrm{bc}$ & $1.4(9.6) \mathrm{bc}$ \\
Pasture_T & $17(367) \mathrm{a}$ & $3.0(12.0) \mathrm{ab}$ \\
Sorghum_F & $14(307) \mathrm{ab}$ & $3.2(14.6) \mathrm{a}$ \\
CV & 90.37 & 51.13 \\
\hline
\end{tabular}

${ }^{1}$ Control = no water deficit; Pasture_G = water supply shortage at the begining from B. brizantha germination; Pasture_T = water supply shortage at the beginning of the $B$. brizantha tillering and at the initiation of the Sorghum bicolor panicle (growth stage II) and Sorghum_F = water supply shortage at the beginning of the Sorghum flowering (growth stage III).

The real data are presented in parenthesis. Average followed by the same letter in the column do not differ by Tukey test at 5\% of significant level. CV = coefficient of variation.

assimilate allocation is to meet requirements of the grains, leaves, stems, branches and finally, of the roots. When the limitations of some of the factors which determine the reduction concerning carbon offer, the demand intensity of each one of the compartments is changed and the priority of the assimilate allocation turns into for roots and reserves.

Dry matter of senescent material did not differ in the treatments ( $937 \mathrm{~kg} / \mathrm{ha} ; \mathrm{P}=0.2087$ ). It is probable that there was a loss of material in the field during the sample collections because a higher amount of senescent material was expected in the two first treatments (Control and Pasture_G).
The lack of water periods affected grain productivity in the sorghum production $(\mathrm{P}<0.0001$; Table 7$)$, mainly when they occurred during the reproduction period, phase of the panicle initiation and the flowering of sorghum. The lowest production in the Pasture_T (Table 7) is related to the smallest size of the panicle (Table 5).

Ney et al. (1994) showed that water deficit caused a significant effect on the reduction of the amount of pea grains when the deficit occurred concomitant or after the flowering. Working with the corn production, Kiniry \& Ritchie (1985) observed the phase in which the amount of grains per corn on the cob is more sensitive to the water deficit two weeks before and three weeks after the anthesis. Tollenaar et al. (1992) observed that the most critical period for the corn ear formation is the flowering phase. The occurrence of water deficit during corn reproduction period reduces the corn on the cob formation (Herrero \& Johnson, 1981).

The results obtained in this work show that the when water deficit occurs in the first phase of the sorghum production growth, which starts at the germination until panicle initiation (Pasture_G), causes less damage to the plant than at the initiation phase of the panicle until flowering (Pasture_T) and in the period from the flourishing to physiological maturation (Sorghum_F). These effects can be attributed to a disorder of the hormonal state of the

Table 7 - Grain dry matter productivity for the sorghum

\begin{tabular}{lc}
\hline Treatment $^{1}$ & Dry matter $(\mathrm{kg} / \mathrm{ha})$ \\
\hline Control & $2475 \mathrm{a}$ \\
Pasture_G & $1708 \mathrm{ab}$ \\
Pasture_T & $958 \mathrm{bc}$ \\
Sorghum_F & $51 \mathrm{c}$ \\
CV $(\%)$ & 44.88 \\
\hline
\end{tabular}

${ }^{1}$ Contol $=$ no water deficit; Pasture_G = water supply shortage from the start of the $B$. brizantha germination; Pasture $\mathrm{T}=$ water supply shortage at the beginning of the $B$. brizantha tillering and at the initiation of the sorghum panicle (growth stage II) and Sorghum_F = water supply shortage at the beginning of Sorghum flowering (growth stage III).

Averages followed by the same letter in the column do not differ by Tukey test at $5 \%$ of significant. CV = Coefficient of variation. 
panicle differing in the Pasture_T treatment (Magalhães \& Durães, 2003a, b).

Photosynthesis has an important role in the production of one crop (Wullschleger \& Oosterhuis, 1990) because the yield of the grains is potentially influenced by the duration of carbohydrate accumulation rate (Crafts-Brandner \& Poneleit, 1992), but because of the stress rigorousness, the cell dehydration of the mesophyll cells inhibit photosynthesis (Taiz \& Zeiger, 2004).

For palisadegrass, there was no effect concerning dry matter treatments of the herbage mass. The average productivity of the leaf dry matter was $549 \mathrm{~kg} / \mathrm{ha}(\mathrm{P}=0.2079$; first harvest ) and 1,281 kg/ha ( $\mathrm{P}=0.1218$; second harvest $)$, the stem dry matter of $424 \mathrm{~kg} / \mathrm{ha}(\mathrm{P}=0.6598$, first harvest $)$ and $1,425 \mathrm{~kg} / \mathrm{ha}(\mathrm{P}=0.0519$; second harvest $)$, the senescent matter was $169 \mathrm{~kg} / \mathrm{ha}(\mathrm{P}=0.1909$; second harvest), LAI was $1.2(\mathrm{P}=0.2972$; first harvest $)$ and $2.7(\mathrm{P}=0.0520$; second harvest) and the SLA was $22 \mathrm{~cm}^{2} / \mathrm{g}(\mathrm{P}=0.1085$; first harvest $)$ and $20 \mathrm{~cm}^{2} / \mathrm{g}(\mathrm{P}=0.0945$; second harvest $)$.

There was no significant interaction between treatment and week for the large amount of tillering density ( $\mathrm{P}=$ 0.9895), but, evaluated weeks $(\mathrm{P}<0.0001)$ and treatments $(\mathrm{P}<0.0001$; Figure 1) were affected.

Pasture_G and Sorghum_F treatments had a smaller number of tillers (Figure 1). In the Pasture_G treatment, soil reached the permanent wilting point during four days before the beginning of the plants tillering, causing water deficit besides nutritional deficit (mainly by the reduction in nitrogen uptake by roots), reducing tillering during the pasture establishment period.

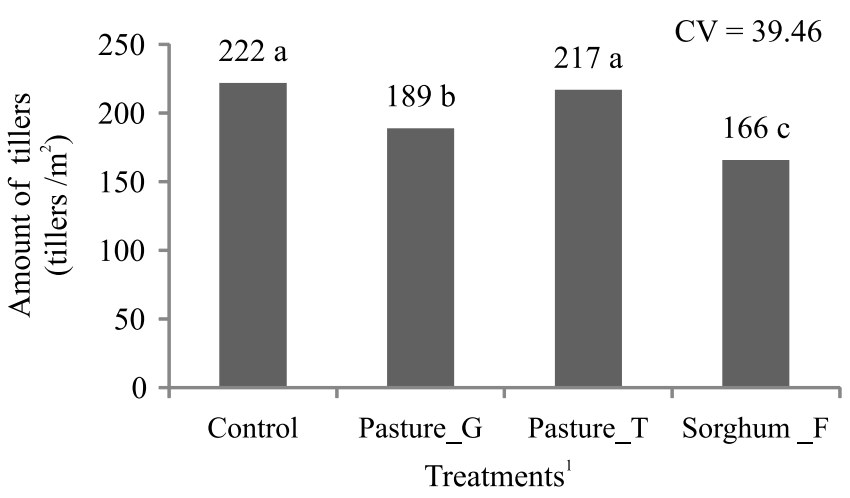

${ }^{1}$ Control = no water deficit; Pasture_G $=$ water supply shortage at the start of $B$. brizantha germination; Pasture_T $=$ water supply shortage at the beginning of the $B$. brizantha tillering and at the Sorghum bicolor panicle initiation (growth stage II) and Sorghum F = water supply shortage at the beginning of the sorghum flowering (growth stage III). The amount is the average of 15 weekly evaluations.

Averages followed by the same letter do not differ by the Tukey test at 5\% of significant. $\mathrm{CV}=$ coefficient of variation.

Figure 1 - Amount of palisadegrass tillers intercropped with sorghum (Cultivar AG1018).
In a study carried out in the greenhouse with Paspalum urvillei seedlings cultivated in washed sand with nutritive solution (Hoagland) submitted to the influence of three levels of nitrogen ( $0.5 ; 7.5$ and $15 \mathrm{~g} \mathrm{~N} /$ plant $)$ and two moisture conditions in the soil (6.4 and 5.4\% of volume water), Soares at al. (2001) verified that the amount of tillers per plant was the most affected variable through the observed treatment interaction, in which the increase of the nitrogen availability did not stimulate plant tillering when the moisture in the soil was kept low (5.4\% of volume water).

Plant tillering reduction under water deficit mainly occurs due to the low immediate availability of nutrients for the growth conditions because the nutrients are absorbed by the root system through the soil solution (Premazzi et al., 2003; Taiz \& Zeiger, 2004).

Nitrogen is absorbed by the plant root system per matter flow, therefore, under lack of water condition, reduction of the cell division occurs in the apical meristem cell differentiation phase. The cell expansion is other process that depends on the cell water conditions, also decreasing with the water deficit (Taiz \& Zeiger, 2004). Thus, the water condition is essential for the vegetal growth, mainly for the tillers emerging in forage plants.

In the Sorghum_F treatment, besides the water stress effect, the most emphasized competition for water, light and nutrients between the Pasture and the Sorghum crops contributed for the lowest amount of tillers. Araujo (2008), working with palisadegrass cultivated in single or intercropped with maize, observed that in the intercropped systems, there is a reduction of tillering rate due to the competition for light.

Forage plants grown in an intercrop system are exposed to the constant shading because, as the crop grows, this one is preventing great part of the incident sunlight and consequently, shading the forage (Tsumanuma, 2004). Thus, the forage plants which develop in intercrop systems present lower tillering, when compared to the single production systems (Portes et al., 2000; Cobucci at al., 2001).

In the Pasture_T, tillering was not delayed, probably because the permanent wilting point was reached only 22 days after the beginning of the plants tillering when the axillary buds had already been stimulated for the initiation of new tillering.

However in the Pasture_G, wilting point was reached only four days before the beginning of the tillering. When the Pasture_T got the water deficit, compared to the Pasture_G, it was at the most advanced development phase and consequently it presented more developed root system, then higher volume of explored soil, increasing the water absorption capacity. 


\section{Conclusions}

Water restriction in the panicle initiation phase or in flowering of sorghum reduces grain productivity. Water deficit starting at palisadegrass germination reduces the tillering during the establishment phase of the intercropped pasture. In a sorghum and palisadegrass production system, the critical water deficit periods correspond to the germination phases of the pasture and the panicle initiation and to the sorghum flowering.

\section{References}

ARAUJO, L.C. Influência da disponibilidade de água no desenvolvimento de plantas de capim marandu e milho: cultivo solteiro e consorciado. 2008. 98f. Dissertação (Mestrado em Ciência Animal e Pastagens) - Escola Superior de Agricultura "Luiz de Queiroz"/Universidade de São Paulo, Piracicaba.

BENNETT, J.M.; SULLIVAN, C.Y. Effect of water stress preconditioning on net photosynthetic rate of grain sorghum. Photosynthetica, v.15, n.3, p.330-337, 1981

BERKOWITZ, G.A. Water and salt stress. In: RAGHAVENDRA, A.S. (Ed.). Photosynthesis: comprehensive treatise. Cambridge: Cambridge University, 1998. p.226-237.

BANZATTO, D.A.; KRONKA, S.N. Experimentação agrícola. 3.ed. Jaboticabal: FUNEP, 1995. 247p.

BRASIL. [2009]. Ministério da Agricultura, Pecuária e Abastecimento. Available at: <http://www.agricultura.gov.br/>. Accessed on: July 1, 2009.

COBUCCI, T.; KLUTHCOUSKI J.; AIDAR, H. Sistema Santa Fé: produção de forragem na entressafra. In: WORKSHOP INTERNACIONAL PROGRAMA DE INTEGRAÇÃO AGRICULTURA E PECUÁRIA PARA O DESENVOLVIMENTO SUSTENTÁVEL DAS SAVANAS TROPICAIS SULAMERICANAS, 2001, Santo Antonio de Goiás. Anais... Santo Antonio de Goiás: Embrapa Arroz e Feijão, 2001. p.125-135. (Documentos, 123).

CRAFTS-BRANDNER, S.J.; PONELEIT, C.G. Selection for seed growth characteristics: effect on leaf senescence in maize. Crop Science, v.32, p.127-131, 1992.

FERREIRA, D.F. SISVAR: um programa para análises e ensino de estatística. Revista Científica Symposium, v.6, n.2, p.36-41, 2008.

HERRERO, M.P.; JOHNSON, R.R. Drought stress and its effects on maize reproductive systems. Agronomy Journal, v.21, p.105-110, 1981.

KINIRY, J.R.; RITCHIE, J.T. Shade-sensitive interval of kernel number of maize. Agronomy Journal, v.77, p.711-715, 1985.

LUDLOW, M.M.; NG, T.T. Effect of water deficit on carbon dioxide exchange and leaf elongation rate of Panicum maximum var. trichoglume. Australian Journal of Plant Physiology, v.3, n.3, p.401-413, 1976.
MAGAlHÃES, P.C.; DURÃES, F.O.M.; RODRIGUES, J.A.S. Fisiologia da planta de sorgo. Sete Lagoas: EMBRAPA Milho e Sorgo, 2003a. 4p. (Comunicado Técnico, 86).

MAGALHÃES, P.C.; DURÃES, F.O.M. Ecofisiologia da produção de sorgo. Sete Lagoas: EMBRAPA Milho e Sorgo, 2003b. 4p. (Comunicado Técnico, 87).

MORAES, A.; MARASChIN, G.E.; NABINGER, C. Pastagens nos ecossistemas de clima sub-tropical: pesquisas para o desenvolvimento sustentável. In: SIMPÓSIO SOBRE PASTAGENS NOS ECOSSISTEMAS BRASILEIROS, 32., 1995, Brasília. Anais... Brasília: Sociedade Brasileira de Zootecnia, 1995. p.147-200.

NEY, B.; DUTHION, C.; TURC, O. Phenological response of pea to water stress during reproductive development. Crop Science, v.34, p.141-146, 1994.

PORTES, T.A.; CARVALHO, S.I.C.; OLIVEIRA, I.P. et al. Análise do crescimento de uma cultivar de braquiária em cultivo solteiro e consorciado com cereais. Pesquisa Agropecuária Brasileira, v.35, n.7, p.1349-1358, 2000.

PREMAZZI, L.M.; MONTEIRO, F.A.; CORRENTE, J.E. Perfilhamento em capim-bermuda cv. Tifton 85 em respostas a doses e ao momento de aplicação do nitrogênio após o corte. Scientia Agricola, v.60, n.3, p.565-571, 2003.

RASSINI, J.B. Irrigação de pastagens: freqüência e quantidade de aplicação de água em latossolos de textura média. São Carlos: EMBRAPA Pecuária Sudeste, 2002. 7p. (Circular Técnica, 31).

SOARES, A.B.; ROSA, L.M.; SILVEIRA, E.O. et al. Água e nitrogênio como determinante do crescimento de Paspalum urvillei. In: REUNIÃO ANUAL DA SOCIEDADE BRASILEIRA DE ZOOTECNIA, 38., 2001, Piracicaba. Anais... Piracicaba: SBZ, 2001. p.317-318.

TAIZ, L.; ZEIGER, E. Fisiologia vegetal. 3.ed. Tradução de E.R. Santarém et al. Porto Alegre: Artmed. 2004. 719p.

TOLLENAAR, M.; DWYER, L.M.; STEWART, D.W. Ear and kernel formation in maize hybrids representing thee decades of grain yield improvement in Ontario. Crop Science, v.32, p.432-428, 1992.

TSUMANUMA, G.M. Desempenho do milho consorciado com diferentes espécies de braquiárias. 2004. 83f. Dissertação (Mestrado em Fitotecnia) - Escola Superior de Agricultura "Luiz de Queiroz”/Universidade de São Paulo, Piracicaba.

UNITED STATES. Department of Agriculture. Soil Survey Division. Soil Conservation Service. Soil Survey Staff. Soil taxonomy: a basic system of soil classification for making and interpreting soil surveys. 2.ed. Washington, 1999. 169p. (USDA. Agriculture Handbook, 436).

VAN LOO, E.N. Tillering, leag expansion and growth of plants of two cultivars of perennial ryegrass grown using hydroponics at two water potential. Annals of Botany, v.70, n.6, p.51-518, 1992.

VAN RAIJ, B.; CATARELlA, H.; QUAGGiO, J.A. et al. Recomendações de adubação e calagem para o Estado de São Paulo. 2.ed. Campinas: Instituto Agronômico; Fundação IAC, 1996. 258p. (Boletim Técnico, 100).

WULLSCHLEGER, S.D.; OOSTERHUIS, D.M. Photosynthetic carbon production and use by developing cotton leaves and bolls. Crop Science, v.30, p.1259-1264, 1990. 